\title{
Analisis Kinerja Keuangan PT. Ace Hardware Indonesia, Tbk
}

\author{
Abd. Rachim, Mansyur \\ Universitas Widya Gama Mahakam Samarinda \\ Agustinus Awang, Ida Ariyani, Kamsiah \\ Universitas Widya Gama Mahakam Samarinda
}

\section{Ringkasan}

Metode penelitian ini bersifat deskriptif dengan menggunakan alat analisis rasio keuangan seperti rasio likuiditas, solvabilitas, dan profitabilitas untuk mengetahui kinerja keuangan perusahaan.

Dari hasilanalisis, diketahui bahwa rasio likuditas memiliki hasil rasio di atas rata-rata rasio industri, rasio solvabilitas memiliki nilai rasio dibawah rata-rata rasio industri,dan rasio profitabilitas memiliki nilai rasio di atas rata-rata rasio industri.

\section{Kata Kunci : Rasio, Likuiditas, Solvabilitas, Profitabilitas}

\section{Latar Belakang}

Perusahaan sebagai salah satu bentuk organisasi pada umumnya memiliki tujuan tertentu yang ingin dicapai dalam usaha untuk memenuhi kepentingan para anggotanya. Keberhasilan dalam mencapai tujuan perusahaan merupakan prestasi dari manajemen. Penilaian prestasi atau kinerja suatu perusahaan diukur karena dapat dipakai sebagai dasar pengambilan keputusan baik pihak internal maupun eksternal. Dimana pada dasarnya hampir seluruh perusahaan bertujuan untuk memperoleh keuntungan profit oriented.

Analisis laporan keuangan merupakan proses yang penuh pertimbangan dalam rangka membantu mengevaluasi posisi keuangan dan hasil operasi perusahaan pada masa sekarang dan masa lalu. Dengan tujuan untuk menentukan estimasi dan prediksi yang paling mungkin mengenai kondisi dan kinerja perusahaan pada masa yang mendatang. Untuk dapat mengetahui dan memahami informasi yang terkandung dalam laporan keuangan diperlukan suatu alat analisis laporan keuangan. Analisis laporan keuangan pada dasarnya ingin melihat prospek dan resiko perusahaan, prospek bisa dilihat dari tingkat keuntungan (profitabilitas) dan resiko bisa dilihat dari kemungkinan perusahaan mengalami kesulitan keuangan atau mengalami kebangkrutan.

Pada dasarnya macam atau jumlah angka-angka ratio itu banyak sekali karena rasio dapat dibuat menurut kebutuhan penganalisa, namun demikian angka-angka rasio yang ada pada dasarnya dapat digolongkan menjadi dua golongan. Golongan pertama adalah berdasarkan sumber data keuangan yang merupakan unsur atau elemen dari angka rasio tersebut. Dan golongan kedua adalah didasarkan pada tujuan dari penganalisa. 
Berdasarkan sumber datanya maka angka ratio dapat dibedakan antara :

1. Ratio-ratio neraca

2. Ratio-ratio laporan laba rugi

3. Ratio-ratio antar laporan

Penggolongan angka ratio yang didasarkan pada sumbernya sebenarnya kurang bermanfaat bagi penganalisa sebab yang penting bagi penganalisa bukan dari mana data itu diperoleh tetapi, apa arti atau gunanya dari data angka ratio tersebut atau kesimpulan apa yang dapat diperoleh dari angka ratio tersebut.

Analisis rasio likuiditas yang digunakn terdiri dari Current Ratio, Quick Ratio, Cash Ratio, Rasio perputaran Kas, dan Inventory to Net Woking Capital. Analisis rasio solvabilitas yag digunakan terdiri dari Debt to Asset Ratio, Debt to Equity ratio,Long Term Debt to Equity Ratio (LTDtER), dan Times Interest Earned. Analisis profitabilitas yang digunakan terdiri dari Net Profit Margin, Return on Investment,danReturn on Equity..

PT Ace Hardware Indonesia tbk (AHI) sebagai salah satu perusahaan yang menjual perlengkapan rumah \& gaya hidup terlengkap, yang juga mengelola beberapa cabang. Perusahaan ini adalah usaha yang berdasarkan ketelitian, kepercayaa, tanggung jawab, dan resiko yang besar. Tantangan yang dihadapi untuk meningkatkan keuntungan dirasakan semakin berat akibat persaingan yang semakin ketat.

Tabel 1.1

Pertumbuhan Laba PT. ACE Hardware Indonesia, Tbk Periode 2013-2017

\begin{tabular}{|c|cc|cc|c|}
\hline Tahun & \multicolumn{2}{|c|}{$\begin{array}{c}\text { Laba Bersih } \\
\text { Tahunt }\end{array}$} & \multicolumn{2}{c|}{$\begin{array}{c}\text { Laba Bersih } \\
\text { Tahunt-1 }\end{array}$} & $\begin{array}{c}\text { Pertumbuhan } \\
\text { Laba }\end{array}$ \\
\hline 2013 & $\mathrm{Rp}$ & 503.004 .239 .918 & $\mathrm{Rp}$ & 428.849 .175 .516 & $17,29 \%$ \\
\hline 2014 & $\mathrm{Rp}$ & 548.892 .765 .278 & $\mathrm{Rp}$ & 503.004 .238 .918 & $9,12 \%$ \\
\hline 2015 & $\mathrm{Rp}$ & 584.873 .463 .989 & $\mathrm{Rp}$ & 548.892 .765 .278 & $6,55 \%$ \\
\hline 2016 & $\mathrm{Rp}$ & 706.150 .082 .276 & $\mathrm{Rp}$ & 584.873 .463 .989 & $2,07 \%$ \\
\hline 2017 & $\mathrm{Rp}$ & 780.686 .814 .661 & $\mathrm{Rp}$ & 706.150 .082 .276 & $1,05 \%$ \\
\hline
\end{tabular}

Sumber : Data diolah, 2018

Dari tabel diatas dapat dilihat bahwa secara nominal terjadi pertumbuhan laba setiap tahunnya, namun secara persentase pertumbuhan laba terjadi penurunan.

\section{Kerangka Teoritis}

\section{Manajemen Keuangan}

Setiap perusahaan selalu membutuhkan dana dalam rangka memenuhi kebutuhan operasi sehari-hari maupun untuk mengembangkan perusahaan. Kebutuhan dana tersebut berupa modal kerja maupun untuk membeli aktiva tetap. Untuk memenuhi dana tersebut, perusahaan harus mampu mencari sumber dana 
dengan komposisi yang menhasilkan beban biaya paling murah, kedua hal tersebut harus bisa diupayakan oleh manajer keuangan.

Kesuksesan suatu perusahaan dipengaruhi oleh kemampuan manajemen keuangan untuk beradaptasi terhadap perubahan, meningkatkan dana perusahaan sehingga kebutuhan perusahaan dapat terpenuhi. Investasi dalam aset-aset perusahaan dan kemampuan untuk mengelola secara bijaksana. Seiring dengan perkembangannya, tugas manajer keuangan tidak hanya mencatat, membuat laporan, mengendalikan posisi kas, membayar tagihan, dan mencari dana. Akan tetapi, manajer keuangan juga harus mampu untuk mengelola dana tersebut sesuai dengan tujuan perusahaan yang telah ditetapkan sebelumnya.

Keseluruhan aktivitas yang bersangkutan dengan usaha untuk mendapatkan dana tersebut merupakan bahasan dalam manajemen keuangan.

Menurut Martono, Manajemen Keuangan adalah : "Manajemen keuangan adalah segala aktiva perusahaan yang berhubungan dengan bagaimana memperoleh dana, menggunakan dana dan mengelola asset sesuai tujuan perusahaan secara menyeluruh.

\section{Analisis Laporan Keuangan}

Analisis terhadap laporan keuangan pada dasarnya karena ingin mengetahui posisi keuangan perusahaan saat ini. Dengan mengetahui posisi keuangan, setelah dilakukan analisis laporan keuangan secara mendalam, akan terlihat apakah perusahaan dapat mencapai target yang telah direncanakan sebelumnya atau tidak.

Menurut Sofyan, Analisis Laporan keuangan adalah : "Analisis laporan keuangan berarti menguraikan akun-akun laporan keuangan menjadi unit informasi yang lebih kecil dan melihat hubungannya yang bersifat signifikan atau yang mempunyai makna antara yang satu dengan yang lain baik antara data kuantitatif maupun data non kuantitatif dengan tujuan untuk mengetahui kondisi keuangan lebih dalam yang sangat penting dalam proses menghasilkan keputusan yang tepat.

\section{Prosedur Analisis Laporan Keuangan}

Menurut Kasmir Sebelum melakukan analisis laporan keuangan, diperlukan langkah-langkah atau prosedur tertentu. Langkah atau prosedur ini diperlukan agar urutan proses analisis mudah untuk dilakukan, adapun langkah atau prosedur yang dilakukan dalam analisis keuangan adalah :

a) Mengumpulkan data keuangan dan data pendukung yang diperlukan selengkap mungkin, baik untuk satu periode maupun beberapa periode.

b) Melakukan pengukuran-pengukuran atau perhitungan-perhitungan dengan rumus tertentu, sesuai dengan standar yang biasa digunakan secara cermat dan teliti, sehingga hasil yang diperoleh benar-benar tepat.

c) Melakukan perhitungan dengan memasukan angka-angka yang ada dalam laporan keuangan secara cermat.

d) Memberikan interpretasi terhadap hasil perhitungan dan pengukuran yang telah dibuat.

e) Membuat laporan tentang posisi keuangan perusahaan. 
f) Memberikan rekomendasi yang dibutuhkan sehubungan dengan hasil analisis tersebut.

\section{Metode dan Teknik Analisis Laporan Keuangan}

Menurut Kasmir, terdapat dua macam metode analisis laporan keuangan yang biasa dipakai, yaitu sebagai berikut :

\section{Analisis Vertikal (Statis)}

Analisis vertikal merupakan analisis yang dilakukan terhadaap hanya satu periode laporan keuangan saja. Analisis dilakukan antar pos-pos yang ada, dalam satu periode. Informasi yang diperoleh hanya untuk satu periode saja dan tidak diketahui perkembangan dari periode ke periode.

2. Analisis Horizontal (Dinamis)

Analisis Horizontal merupakan analisis yang dilakukan dengan membandingkan laporan keuangan untuk beberapa periode. Dari hasil analisis ini akan terlihat perkembangan perusahaan dari periode satu ke periode lainnya.

Kemudian, disamping metode yang digunakan untuk menganalisis laporan keuangan, terdapat beberapa jenis teknik analisis laporan keuangan. Adapun jenisjenis teknik analisis laporan keuangan yang dapat dilakukan menurut Kasmir adalah sebagai berikut :

1. Analisis perbandingan antara laporan keuangan, merupakan analisis yang dilakukan dengan membandingkan laporan keuangan lebih dari satu periode.

2. Analisis Trend, merupakan analisis laporan yang biasanya dinyatakan dalam persentase tertentu. Analisis ini dilakukan dari periode ke periode sehingga akan terlihat apakah perusahaan mengalami perubahan yaitu naik, turun, atau tetap, serta seberapa besar perubahan tersebut yang dihitung dalam persentase.

3. Analisis Persentase Per Komponen, merupakan analisis yang dilakukan untuk membandingkan antara komponen yang ada dalam suatu laporan keuangan, baik yang ada di neraca maupun laporan laba rugi.

4. Analisis sumber dan penggunaan dana, merupakan analisis yang dilakukan untuk mengetahui sumber-sumber dana perusahaan dan penggunaan dana dalam satu periode. Analisis ini juga untuk mengetahui jumlah modal kerja dan sebab-sebab berubahnya modal kerja perusahaan dalam suatu periode.

5. Analisis sumber dan penggunaan kas,merupakan analisis yang digunakan untuk mengetahui sumber-sumber kas perusahaan dan penggunaan uang kas dalaam satu periode. Selain itu, juga untuk mengetahui sebab-sebab berubahnya jumlah uang kas dalam periode tertentu. 
6. Analisis ratio, merupakan analisis yang digunakan untuk mengetahui hubungan pos-pos yang ada dalam satu laporan keuangan atau pos-pos antara laporan keuangan neraca dan laporan laba rugi.

7. Analisis kredit, merupakan analisis yang digunakan untuk menilai layak tidaknya suatu kredit dikucurkan oleh lembaga keuangan seperti bank.

8. Analisis laba kotor, merupakan analisis yang digunakan untuk mengetahui jumlah laba kotor dari periode satu ke periode, kemudian juga untuk mengetahui sebab berubahnya laba kotor tersebut antara periode.

Analisis titik pulang disebut juga analisis titik impas atau break event point, tujuan analisis ini untuk mengetahui pada kondisi berapa penjualan produk dilakukan dan perusahaan tidak mengalami kerugian.

\section{Analisis Rasio Keuangan}

Menurut Kasmir, analisis rasio keuangan suatu perusahaan dapat digolongkan menjadi sebagai berikut :

1. Rasio Neraca, yaitu membandingkan angka-angka yang hanya bersumber dari neraca.

2. Rasio laporan laba rugi, yaitu membandingkan angka-angka yang hanya bersumber dari laporan laba-rugi.

\section{Kinerja Keuangan}

Kinerja keuangan perusahaan dapat dilihat dan diukur dengan cara menganalisis laporan keuaangan yang tersedia. Melalui analisis laporan keuangan, keadaan dan perkembangan financial perusahaan serta hasil-hasil yang telah dicapai perusahaan dapat diketahui. Baik diwaktu lampau maupun di waktu yang sedang berjalan sehubungan dengan penelitian strategi perusahaan yang akan diterapkan. Kinerja adalah gambaran yang mengenai tingkat pencapaian pelaksanaan suatu kegiatan dalam mewujudkan sasaran, tujuan, misi dan visi organisasi yang terutang dalam perencanaan strategi suatu organisasi.

Pengukuran kinerja adalah suatu proses penilaian kemajuan pekerjaan terhadap tujuan dari sasaran yang telah ditentukan sebelumnya. Termasuk informasi atas efisiensi penggunaan sumber daya dalam menghasilkan barang dan jasa, kualitas barang dan jasa, hasil kegiatan dibandingkan dengan maksud yang diinginkan, dan efektivitas tindakan dalam mencapai tujuan.

\section{Metode Penelitian}

Penelitian ini menggunakan metode penelitian deskriptif, penelitian deskriptif adalah jenis penelitian yang berupa mendeskripsikan atau menggambarkan data yang telah terkumpul. Jenis data yang digunakan dalam penelitian ini menggunakan data kuantitatif, berupa laporan keuangan PT Ace Hardware Indonesia yang terdaftar di Bursa Efek Indonesia yang terdiri dari neraca dan laporan laba rugi selama periode penelitian tahun 2013 sampai tahun 2017.

\section{Metode Analisis}


Alat analisis yang digunakan untuk mengukur laporan keuangan adalah sebagai berikut :

\section{Rasio Likuiditas}

Merupakan rasio yang digunakan untuk mengukur kemampuan perusahaan dalam memenuhi kewajiban finansial jangka pendek yang berupa hutang jangka pendek atau hutang lancar, rasio ini antara lain adalah :

a) Current ratio

Current ratio merupakan perbandingan antara aset lancar dengan hutang lancar. Dari hasil peengukuran rasio, apabila rasio lancar rendah, dapat dikatakan bahwa perusahaan kurang modal untuk membayar utang. Namun, apabila hasil pengukuran rasio tinggi, belum tentu kondisi perusahaan sedang baik. Hal ini dapat saja terjadi karena kas tidak digunakan sebaik mungkin.

$$
\text { Current ratio }=\frac{\text { aset lancar }}{\text { hutanglancar }}
$$

b) Quick ratio

Rasio cepat (quick ratio) merupakan rasio yang menunjukan kemampuan perusahaan dalam memenuhi atau membayar kewajiban atau utang lancar dengan aktiva lancar tanpa memperhitungkan nilai sediaan. Artinya nilai sediaan kita abaikan, dengan cara dikurangi dari nilai total aktiva lancar. Hal ini dilakukan karena sediaan dianggap memerlukan waktu relative lebih lama untuk diuangkan, apabila perusahaan membutuhkan dana cepat untuk membayar kewajibannya dibandingkan dengan aktiva lancar lainnya.

c) Cash Ratio

$$
\text { Quick ratio }=\frac{\text { aset lancar-persediaan }}{\text { hutanglancar }}
$$

Cash ratio adalah rasio yang membandingkan antara kas dengan aset lancar yang biasa segera dapat dijadikan kas dengan hutang lancar. Aset lancar yang bisa segera dapat diungkan menjadi kas adalah efek atau surat berharga.

\section{d) Rasio Perputaran Kas}

$$
\text { Cash ratio }=\frac{\text { kas }+ \text { efek }}{\text { hutanglancar }} \times 100
$$

Rasio ini berfungsi untuk mengukur tingkat kecukupan modal kerja perusahaan yang dibutuhkan untuk membayar tagihan dan membiayai penjualan. Artinya rasio ini digunakan untuk mengukur tingkat ketersediaan kas untuk membayar tagihan (utang), dan biaya-biaya yang berkaitan dengan penjualan. Rumus yang digunakan untuk mencari rasio ini adalah sebagai berikut :

\section{e) Inventory to Net Working Capital}

$$
\text { Rasio peputaran kas }=\frac{\text { penjualanbersih }}{\text { modalkerjabersih }} \times 100
$$


Merupakan rasio yang digunakan unutk mengukur atau membandingkan antara jumlah sediaan yang ada dengan modal kerja perusahaaan. Modal kerja tersebut terdiri dari pengurangan antara aktiva lancar dengan utang lancar, rumus yang digunakan untuk mecari rasio ini adalah :

$$
\text { Inventory to NWC }=\frac{\text { inventoy }}{\text { current asset-current liabilities }} \times 100
$$

\section{Rasio Solvabilitas}

rasio ini mengukur perbandingan dana yang disediakaan oleh pemilik dengan dana yang dipinjam AHI dari kreditur. Rasio ini menunjukan kemampuan AHI untuk memenuhi kewajiban finansialnya. Rasio ini dimaksudkan untuk mengukur indikasi tingkat keamanan dari para pemberi pinjaman (bank), rasio ini antara lain adalah :

a) Debt to asset ratio (DAR)

Debt ratio merupakan ratio utang yang digunakaan untuk mengukur perbandingan antara total utang dengan total aktiva. Dengan kata lain, seberapa besar aktiva perusahaan dibiayai oleh utang atau seberapa besar utang perusahaan berpengaruh terhadap pengelolaan aktiva.

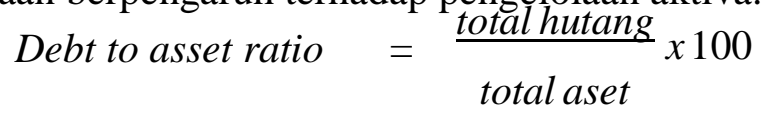

b) Debt to equity ratio(DER)

Debt to equity ratio merupakan rasio yang digunakan untuk menilai utang dengan ekuitas. Rasio ini dicari dengan cara membandingkan antara seluruh utang, termasuk utang lancar dengan seluruh ekuitas. Rasio ini berguna untuk mengetahui jumlah dana yang disediakan peminjam (kreditor) dengan pemilik perusahaan, dengan kata lain rasio ini berfungsi untuk mengetahui setiap rupiah modal sendiri yang dijadikan untuk jaminan utang.

$$
\text { Debt to equity ratio }=\frac{\text { totalhutang }}{\text { total ekuitas }} \times 100
$$

c) Long term Debt to Equity Ratio (LTDtER)

LTDtER merupakan rasio antara utang jangka panjang dengan modal sendiri. Tujuannya adalah untuk mengukur berapa bagian dari setiap rupiah modal sendiri yang dijadikan jaminan utang jangka panjang dengan cara membandingkan antara utang jangka panjang dengan modal sendiri yang disediakan oleh perusahaan. Rumus yang digunakan adalah sebagai berikut :

$$
\text { LTDtER }=\frac{\text { total hutang jangka panjang }}{\text { total ekuitas }} \times 100
$$

d) Times Interst Earned

Untuk mengukur rasio ini, digunakan perbandingan antara laba sebelum bunga dan pajak (earning before interst and tax) dibandingankan dengan biaya 
bunga yang dikeluarkan. Rumus untuk mencari times interst eraned adalah sebagai berikut :

\section{Rasio Profitabilitas}

$$
\text { Times Interest Earned }=\frac{\text { EBIT }}{\text { bebanbunga }} \times 100
$$

Rasio ini digunakan untuk mengungkapkan kemampuan AHI dalam menghasilkan laba atau keuntungan (profit), yang dimana profitabilitas perusahaan AHI mewujudkan perbandingan antara laba perusahaan didapat dengan total aset atau modal yang menghasilkan laba tersebut.

Yang termasuk rasio ini yaitu:

a) Net profit margin

. Rumus yang digunakan ialah :

Net profit margin $=\frac{\text { earning afterinterest } \mathbf{A} \operatorname{tax}(E A T)}{\text { penjualan }} \times 100$

b) Return on investment (hasil pengembalian investasi)

Merupakan rasio yang menunjukan hasil (return) atas jumlah aktiva yang digunakan dalam perusahaan. ROI juga merupakan suatu ukuran tentang efektivitas manajemen dalam mengelola investasinya.

$$
R O I=\frac{E A T}{\text { total aset }} \times 100 \%
$$

c) Return on equity (hasil pengembalian ekuitas)

- Artinya posisi pemilik perusahaan semakin kuat, demikian pula sebaliknya.

$$
R O E=\frac{E A T}{\text { total ekuitas }} \times 100 \%
$$

\section{Hasil Penelitian}

Adapun hasil penelitian yang dapat dihelaskan dari uraian diatas tentang rasio keuangan sebagai berikut

Tabel 4.1 Ringkasan Hasil Perhitungan Analisis Rasio 


\begin{tabular}{|c|c|c|c|c|c|c|c|c|c|c|}
\hline \multirow{2}{*}{ Rasio } & \multicolumn{5}{|c|}{ HesilPerhitungen } & \multicolumn{5}{|c|}{ Rataratarasioindustri } \\
\hline & 2013 & 2014 & 2015 & 2016 & 2017 & 2013 & 2014 & 2015 & 2016 & 2017 \\
\hline \multicolumn{11}{|l|}{ UIUIDTAS } \\
\hline Qurrent Ratio & $4 \mathrm{x}$ & $6 \mathrm{x}$ & $6 \mathrm{x}$ & $7 \mathrm{x}$ & $7 \mathrm{x}$ & $3 x$ & $3 x$ & $3 x$ & $2 x$ & $3 x$ \\
\hline QuidkRatio & $1,44 x$ & $2,27 x$ & $2,29 \mathrm{x}$ & $3,17 \mathrm{x}$ & $3,15 \mathrm{x}$ & $1,7 x$ & $2,5 x$ & $2 x$ & $1,1 x$ & $1,5 x$ \\
\hline Cash ratio & $37 x$ & $92 x$ & $150 x$ & $181 \mathrm{x}$ & $188 x$ & $17 x$ & $33 x$ & $42 x$ & $39 x$ & $36 x$ \\
\hline Rasio perputaran kas & $3 x$ & $3 x$ & $2 \mathrm{x}$ & $2 x$ & $2 x$ & $5 x$ & $3 x$ & $4 x$ & $7 x$ & $5 x$ \\
\hline Inventory to Net Working Capital & $85 \%$ & $74 \%$ & $74 \%$ & $65 \%$ & $64 \%$ & $34 \%$ & $23 \%$ & $19 \%$ & $16 \%$ & $15 \%$ \\
\hline \multicolumn{11}{|l|}{ SOLVABIITAS } \\
\hline Debt to Asset Ratio & $23 \%$ & $20 \%$ & $20 \%$ & $18 \%$ & $21 \%$ & $44 \%$ & $45 \%$ & $52 \%$ & $58 \%$ & $59 \%$ \\
\hline Debt to Equity Ratio & $29 \%$ & $25 \%$ & $24 \%$ & $22 \%$ & $26 \%$ & $16 \%$ & $14 \%$ & $13 \%$ & $27 \%$ & $30 \%$ \\
\hline LTDtR & $6 \%$ & $7 \%$ & $9 \%$ & $10 \%$ & $13 \%$ & $13 \%$ & $12 \%$ & $11 \%$ & $11 \%$ & $13 \%$ \\
\hline TimesInterst Eamed & $35 x$ & $58 x$ & $46 x$ & $45 x$ & $42 x$ & $26 x$ & $19 x$ & $17 x$ & $22 x$ & $20 x$ \\
\hline \multicolumn{11}{|l|}{ PROFTABIUTAS } \\
\hline Profit Margin on Sales & $13 \%$ & $12 \%$ & $12 \%$ & $14 \%$ & $13 \%$ & $5 \%$ & $5 \%$ & $8 \%$ & $11 \%$ & $7 \%$ \\
\hline ROI & $20 \%$ & $19 \%$ & $18 \%$ & $19 \%$ & $18 \%$ & $8 \%$ & $14 \%$ & $12 \%$ & $11 \%$ & $11 \%$ \\
\hline ROE & $26 \%$ & $23 \%$ & $22 \%$ & $23 \%$ & $22 \%$ & $15 \%$ & $12 \%$ & $12 \%$ & $17 \%$ & $13 \%$ \\
\hline
\end{tabular}

Sumber : data diolah penulis, 2018

\section{Pembahasan hasil penelitian}

Sebagaimana hasil analisis pada laporan keuangan perusahaan pada tahun 2013 sampai tahun 2017 dengan rasio likuiditas, solvabilitas, dan profitabilitas, maka dapat dibuat pembahasan sebagai berikut :

Rasio Likuiditas

Gambar IV.1 : Grafik hasil analisis curent ratio 


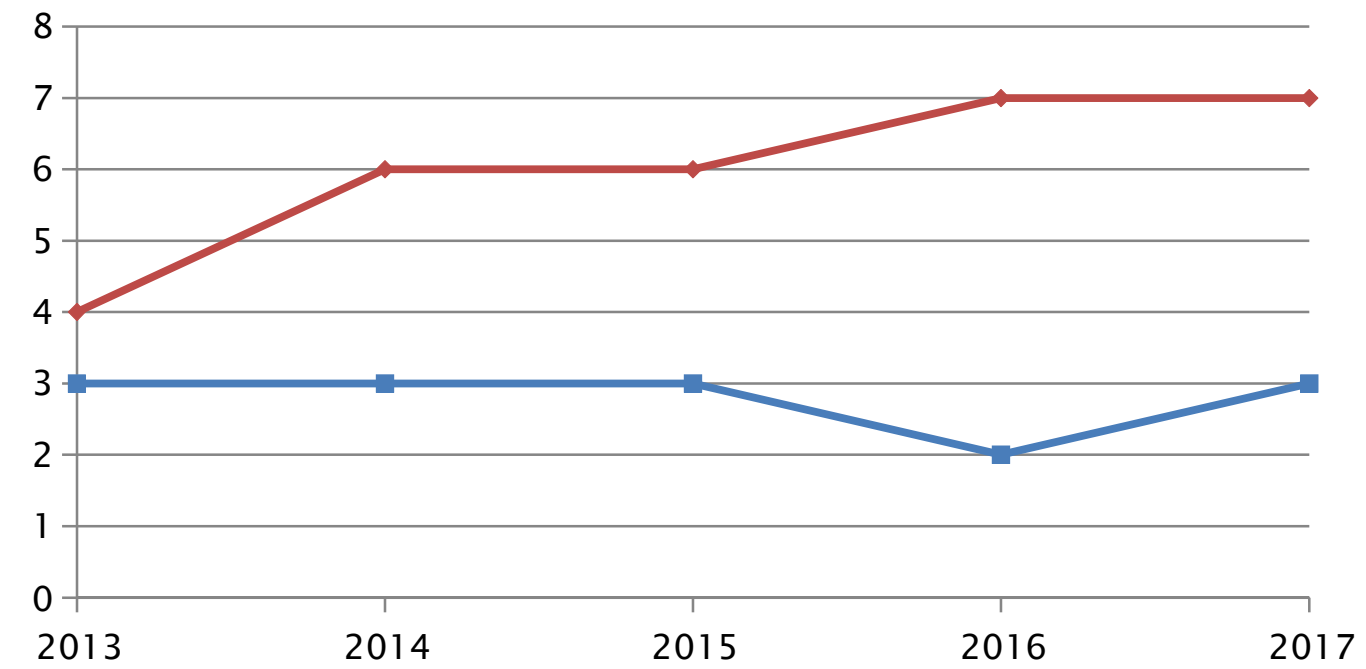

Current ratio periode 2013-2017 mengalami peningkatan setiap tahunnya, dan rasio yang dihasilkan menunjukan angka diatas rata-rata rasio industri yaitu, 4 kali (2013), 6 kali (2014), 6 kali (2015), 7 kali (2016), 7 kali (2017). Ini berarti perusahaan mampu melunasi hutang lancarnya dengan aktiva lancarnya tetapi Rasio yang dihasilkan cukup tinggi ini menunjukan kondisi yang kurang baik bagi perusahaan, karena PT AHI tidak dapat mengelola aktiva lancarnya dengan baik hal ini disebabkan oleh penumpukan persediaan sehingga menghasilkan rasio yang tinggi.

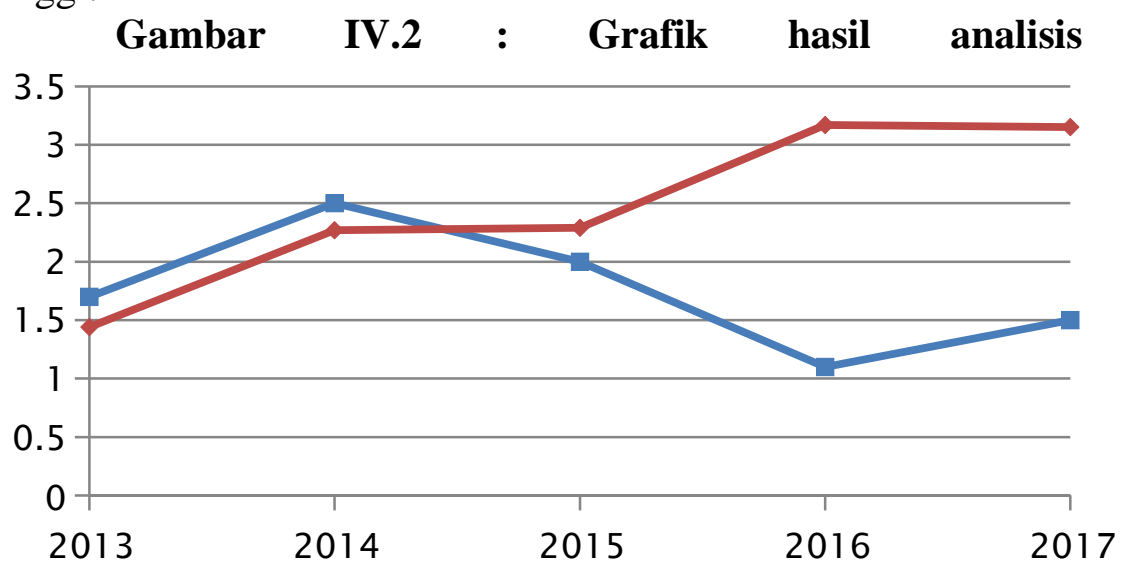

PT Ace Hardware Indonesia, berdasarkan analisis rasio cepat menunjukan bahwa pada tahun 2013 dan 2014 berada dibawah rata-rata rasio industri sedangkan tahun 2015-2017 berada diatas standar rasio inndustri yaitu : 1,44 kali (2013), 2,27 kali (2014), 2,29 kali (2015), 3,17 kali(2016), 3,15 kali (2017). Hal tersebut menunjukan bahwa adanya kemampuan perusahaan dalam membayar utang lancar dengan menggunakan aktiva lancar (tanpa persediaan).

\section{Gambar IV.3 : Grafik hasil analisis cash ratio}




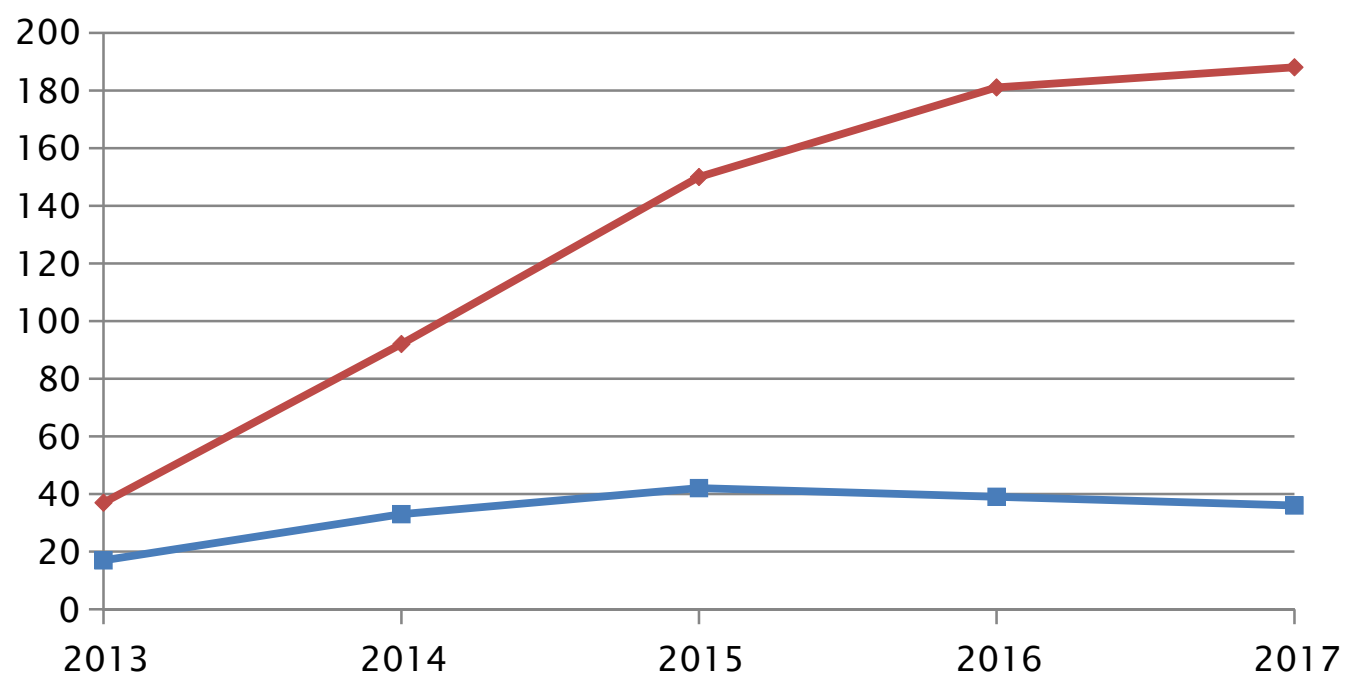

Cash ratio periode 2013-2017 mengalami peningkatan setiap tahunnya, rasio yang dihasilkan menunjukan angka diatas rata-rata industri yaitu senilai, 37\%(2013), $105 \%$ (2014), 150\% (2015), 181\%(2016), 188\%(2017). ini menunjukan kondisi yang kurang baik bagi perusahaan karena apabila rasio yang dihasilkan diatas rata-rata rasio industri ini berarti banyak kas yang tertanam atau ada dana yang menganggur dan tidak digunakan secara optimal.

\section{Gambar IV.4 : Grafik hasil analisis rasio perputaran kas}

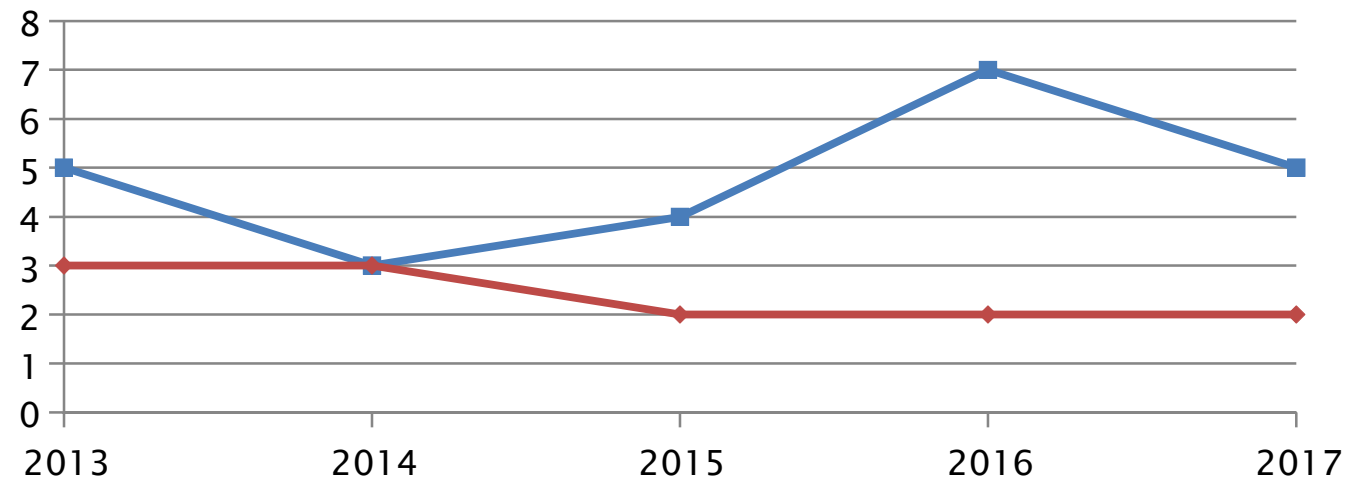

Berdasarkan analisis rasio perputaran kas, untuk tahun 2013 sampai dengan tahun 2017 nilai rasio yang diperoleh PT Ace Hardware Indonesia berada di bawah rata-rata industri dan cenderung stagnan dengan rata-rata nilai persentase yang sama yaitu 3x dan 2x. Perputaran kas yang rendah menunjukan bahwa perusahaan tidak atau kurang mampu memaksimalkan penggunaan kas nya dan menghasilkan pendapatan bagi perusahaan.

\section{Gambar IV.5 : Grafik hasil analisis rasio iventory to net working capital}




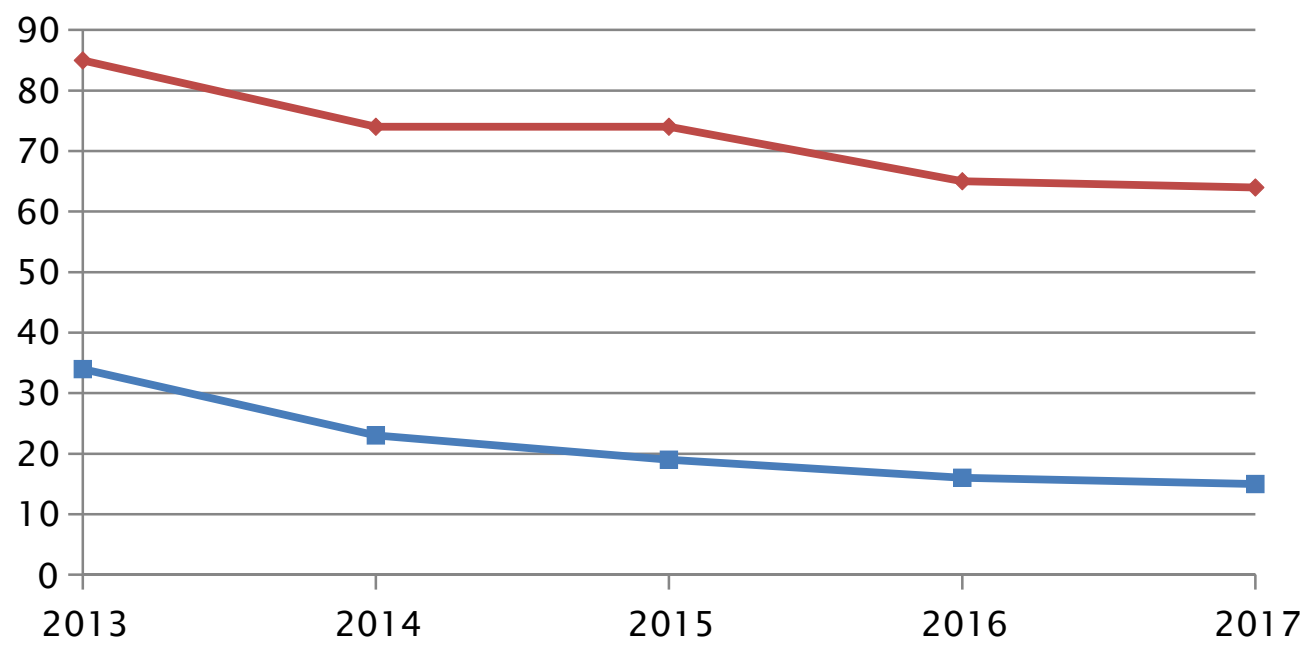

PT Ace Hardware Indonesia, berdasarkan analisis inventory to net working capital menunjukan bahwa nilai selama 5 tahun periode tersebut berada diatas ratarata rasio industri yaitu : 85\% (2013), 74\% (2014), 74\% (2015), 65\% (2016), 64\% (2017). Sehingga dapat diartikan bahwa banyak modal yang tidak berputar dan tertahan di persediaan.. namun grafik menunjukan penurunan setiap tahunnya ini berarti perusahaan sudah ada perbaikan dan mengurangi persediaannya

\section{Rasio Solvabilitas}

\section{Gambar IV.6 : Grafik hasil analisis rasio debt to asset ratio}

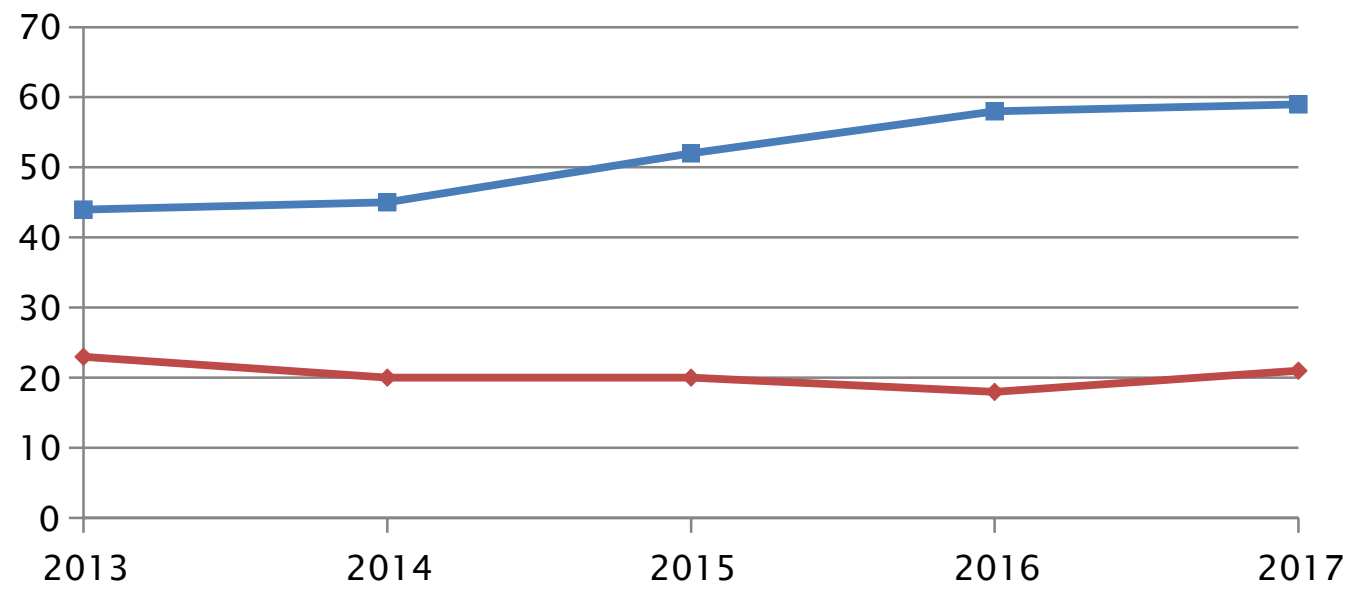

Berdasarkan analisis debt to asset ratio untuk tahun 2013 sampai tahun 2017 PT Ace Hardware Indonesia berada dibawah rata-rata ratio industri yaitu, 23\% (2013), 20\% (2014), 20\% (2015), 18\% (2016), 21\% (2017), Rasio menunjukan hasil diatas rata-rata rasio industri namun angka yang dihasilkan sangat kecil Dengan kata lain dalam rasio ini perusahaan untuk tahun 2013 sampai dengan tahun 2017 dalam keadaan kurang baik. Ini artinya Untuk tahun 2013 setiap Rp.100,- total aktiva yang 
dilakukan dibelanjai dari utang sebesar Rp.29,- atau terdapat 29\% aktiva perusahaan dibelanjai dari hutang dan begitu pula untuk tahun yang lainnya.

\section{Gambar IV.7 : Grafik hasil analisis rasio debt to equity ratio}

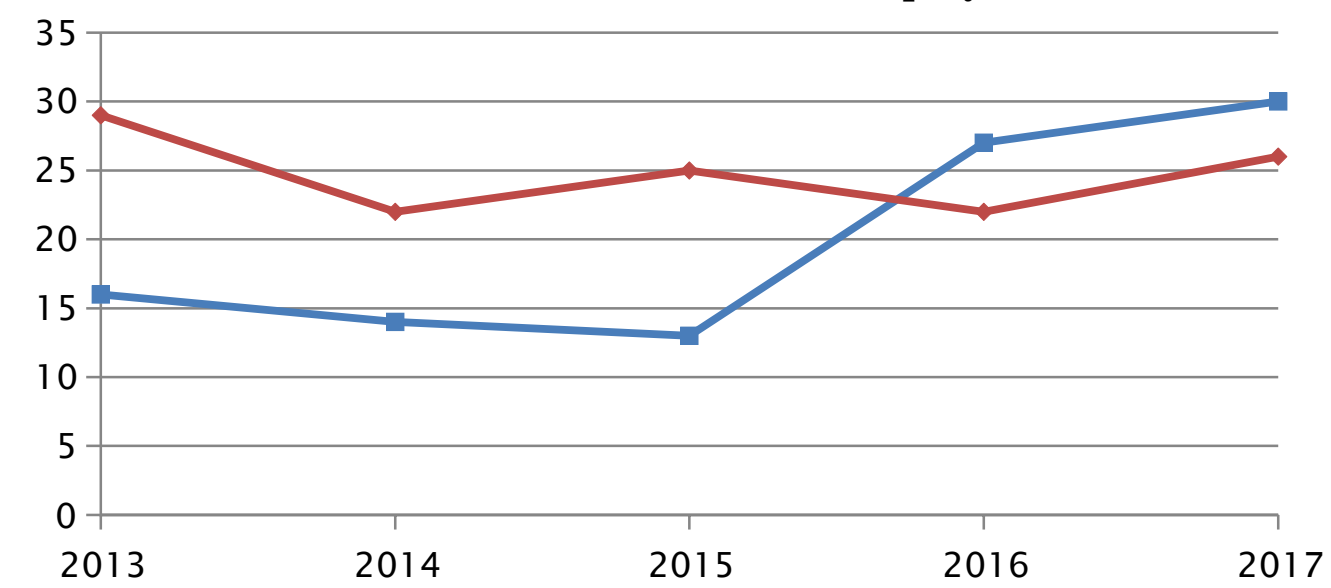

Berdasarkan analisis debt equity ratio, PT Ace Hardware Indonesia untuk tahun 2013-2015 berada diatas rata-rata rasio industri namun untuk tahun 2016-2017 berada dibawah rata-rata rasio industri yaitu : 29\% (2013), 25\% (2014), 24\% (2015), $22 \%$ (2016), 26\% (2017). dalam hal ini perusahaan memiliki rasio yang kurang baik karena perusahaan belum mampu memaksimalkan potensi perusahaan untuk memperoleh modal kerja diluar dari modal yang disetor oleh pemilik.

\section{Gambar IV.8 : Grafik hasil analisis rasio LTDtER}

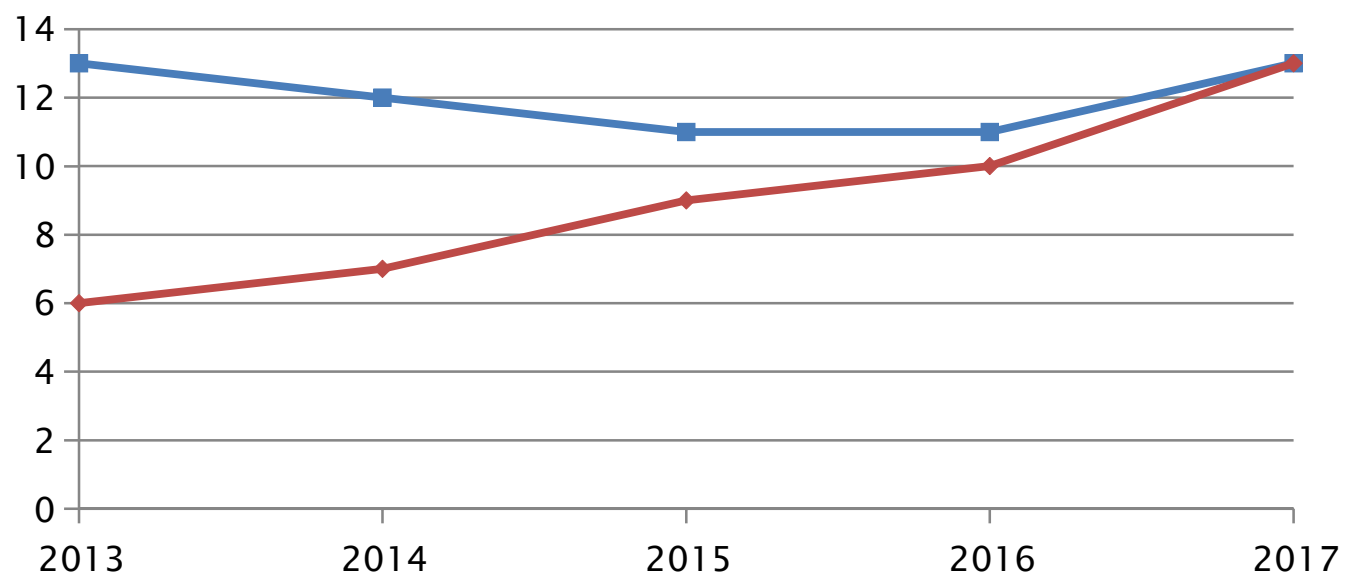

Berdasarkan analisis LTDtER, PT ACE Hardware Indonesia pada tahun 2013- 2017 menunjukan rasio yang berada dibawah rata-rata rasio industri yaitu, 6\%(2013), 7\%(2014), 9\%(2015), 10\%(2016), 13\%(2017).

Gambar IV.9 : Grafik hasil analisis rasio Times Interst Earned 


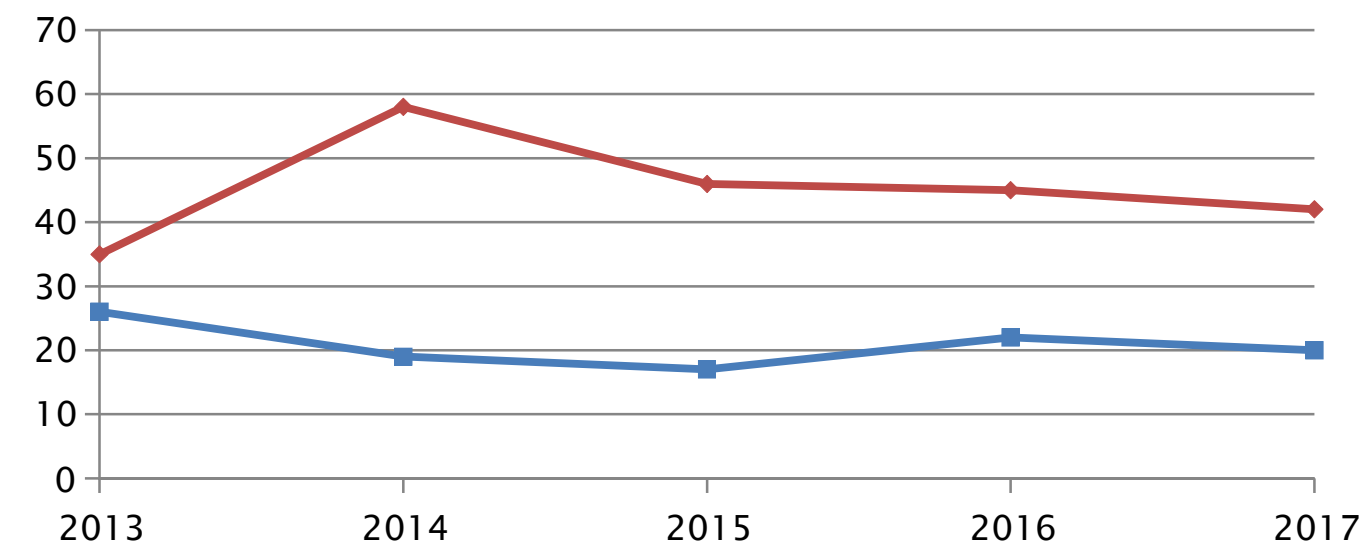

Berdasarkan analisis Times Interst Earned, untuk tahun 2013 sampai dengan tahun 2017 rasio berada diatas rata-rata rasio industri yaitu, 35\% (2013), 58\%(2014), 46\%(2015), 45\%(2016), 42\%(2017), analisis tersenut menunjukan bahwa pendapatan perusahaan sebelum bunga dan pajak dapat menutupi biaya-biaya pinjaman perusahaan.

\section{Rasio Profitabilitas}

\section{Gambar IV.10 : Grafik hasil analisis net profit margin}

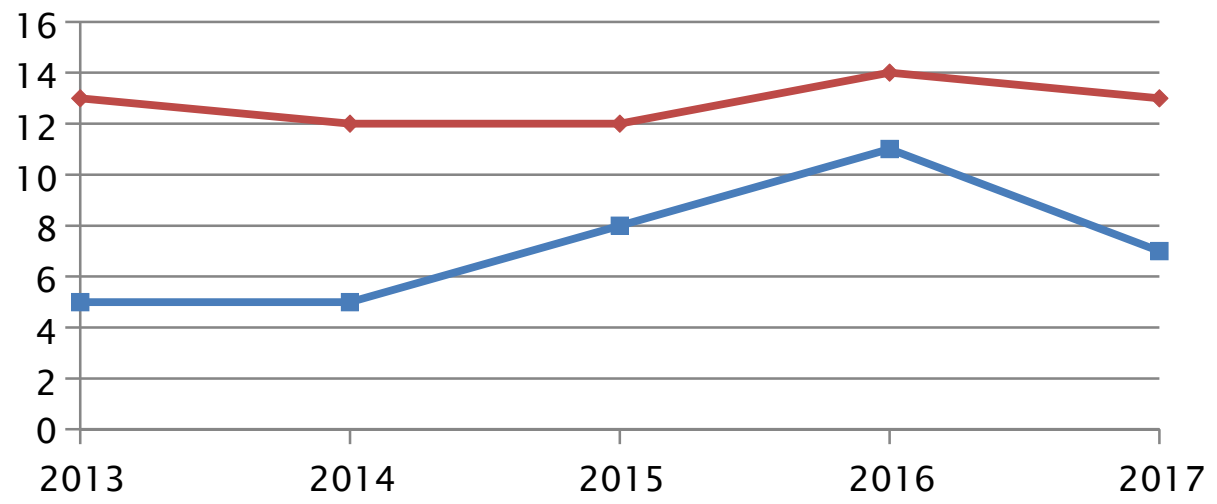

Berdasarkan analisis net profit margin pada tahun 2013 hingga 2017 PT Ace Hardware Indonesia memiliki nilai rasio yang berfluktuasi dan berada diatas rata-rata rasio industri yaitu 13\% (2013), 12\% (2014), 12\%(2015), 14\%(2016), 13\%(2017), sehingga pendapatan bersih perusahaan atas penjualan berada dalam kondisi yang baik.

\section{Gambar IV.11 : Grafik hasil analisis ROI}




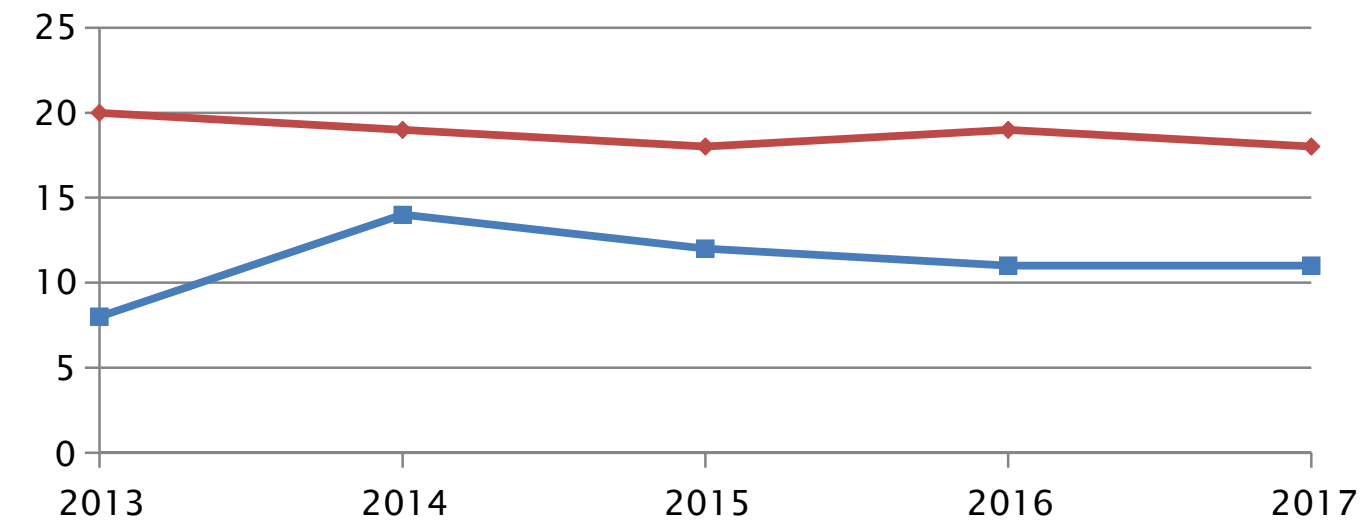

Berdasarkan analisis return on investment, PT Ace Hardware Indonesia cenderung fluktuasi dari periode 2013 hingga 2017 yaitu senilai 20\% (2013), 19\% (2014), 18\% (2015), 19\% (2016), 18\% (2017), berdasarkan nilai yang telah diperoleh tersebut memperlihatkan bahwa nilai yang di peroleh berada diatas rata-rata rasio industri. Sehingga hasil (return) atas jumlah aktiva yang digunakan dalam perusahaan tersebut dalam kondisi yang baik.

\section{Gambar V.12 : Grafik hasil analisis ROE}

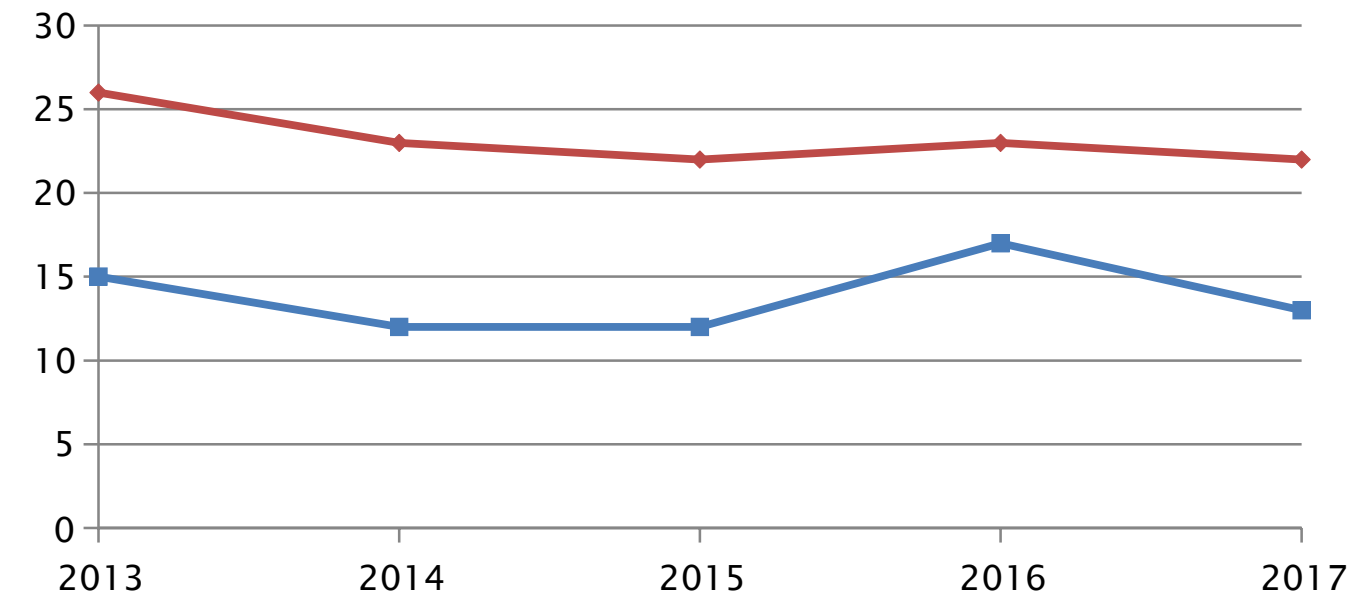

Berdasarkan analisis return on equity tahun 2013 sampai tahun 2017 menunjukan angka diatas rata-rata rasio industri yaitu sebesar 26\% (2013), 23\% (2014), 22\% (2015), 23\% (2016), 22\% (2017). Ini berarti hasil atas pengembalian ekuitas dalam keadaan baik.

\section{Kesimpulan}

Dari uraian diatas telah dikemukakan hasil analisis rasio likuiditas, solvabilitas, dan profitabilitas pada PT Ace Hardware Indonesia Tbk sehingga penulis dapat mengambil kesimpulan sebagai berikut :

1. Rasio Likuiditas

Kinerja perusahaan PT Ace Hardware Indoesia Tbk berdasarkan hasil perhitungan analisis rasio likuiditas dapat dikatakan kurang baik karena 
perusahaan tidak mampu mengelola aktiva lancarnya dengan baik sehingga terjadi penumpukan kas dan penumpukan persediaan.

2. Rasio Solvabilitas

Kinerja perusahaan PT. Ace Hardware Indonesia Tbk berdasarkan analisis rasio solvabilitas dapat dikatakan kurang baik karena PT AHI lebih banyak membiayai perusahaan dengan modal sendiri bukan berasal dari pinjaman kepada pihak lain, karena bagi suatu perusahaan yang terpenting adalah bagiamana menghasilkan laba dengan modal yang sekecil mungkin dan alangkah lebih baik jika menggunakan modal dari pihak lain .

3. Rasio Profitabilitas

Kinerja perusahaan PT Ace Hardware indonesia Tbk berdasarkan analisis rasio profitabilitas dapat dikatakan baik karna mampu menghasilkan rasio diatas rata-rata rasio industri.

4. Dari kondisi likuiditas, solvabilitas, dan profitabilitas dapat disimpulkan bahwa fenomena penurunan persentase pencapaian laba PT. Ace Hardware Indonesia disebabkan karena ratio likuditas atau kas tidak berputar secara maksimal, sehingga labanya secara rupiah mengalami peningkatan setiap tahun namun secara persentase tidak mengalami kenaikan.

\section{DAFTAR PUSTAKA}

Ahmed, Riahi. Teori Akuntansi, Salemba Empat, 2004, Jakarta

Astuti, Dewi, Manajemen keuangan perusahaan, Ghalia indonesia, 2004, Jakarta

Baridwan, Zaki. Intermediate Accounting, BPFE, 2006, Yogyakarta

Halim, Abdul. Akuntansi Keuangan Daerah, salemba empat, jakarta

Harahap, Sofyan Safitri. Analisis Kritis Laporan Keuangan, PT Raja

Grafindo Persada, 2006, Jakarta

Ikatan Akuntan Indonesia, Standar Akuntansi Keuangan, Salemba Empat, 2009, Jakarta

Jususp, Al. Haryono. Dasar-Dasar Akuntansi, BPSTIE YKPN, 2009, Yogyakarta

Kasmir, Analisis Laporan Keuangan, Rajawali, 2014, Jakarta

Kieso, Donald E. dan Weigand, Dasar-Dasar Akuntansi, BPSTIE YKPN, 2008, Yogyakarta

Machfoedz, Mas'ud dan Mahmudi, Akuntansi Manajemen, Liberty, 2008, Yogyakarta

Martono, Manajemen Keuangan, Ekonisia, 2012, Yogyakarta

Munawir, S. Analisis Laporan Keuangan, Liberty, 2014, Yogyakarta

Riyanto, Dasar-dasar Pembelanjaan Perusahaan, BPFE, 2011, Yogyakarta

Sutrisno, Manajemen Keuangan, Ekonisia, 2007, Yogyakarta 